\title{
PERAN MODAL SOSIAL, POTENSI PARIWISATA DAN PEMBERDAYAAN MASYARAKAT PADA PEMBANGUNAN PARIWISATA BERBASIS MASYARAKAT DI KAWASAN STRATEGIS PARIWISATA LEBIH
}

\author{
I Dewa Gede Ngurah ${ }^{1}$ \\ Made Suyana Utama \\ ${ }^{1,2}$ Fakultas Ekonomi dan Bisnis Universitas Udayana (Unud), Bali, Indonesia \\ Email : dewagedengurah64@gmail.com
}

\begin{abstract}
ABSTRAK
Tujuan utama pembangunan mengurangi kesenjangan yang terjadi di masyarakat, tantangan utama pembangunan pada jaman kita saat ini adalah tantangan terhadap timbulnya penyatuan (inclusion). Konsep pembangunan untuk Bali seharusnya disesuikan dengan potensi dan kondisi yang dimiliki oleh Bali sendiri, dengan selalu mencermati perubahan kesenjangan yang terjadi setiap saat. Sektor pariwisata merupakan potensi pembagunan untuk dikembangkan. Sektor pariwisata di provinsi Bali merupakan sektor penompang pendapatan. Perkembangan sektor pariwisata di Bali tersebar di seluruh kabupaten/kota, salah satunya adalah Kabupaten Gianyar. Perkembangan pembangunan di sektor pariwisata sebaiknya dilakukan secara berkelanjutan (sustainable) dengan memanfaatkan masyarakat lokal sebagai pengelola, sehingga tidak menggeser paradigma pariwisata di daerah yang kaya akan adat istiadat, potensi alam (sawah, gunung dan laut). Teknik analisis yang digunakan adalah analisis persamaan structural dengan alternative Partial Least Square (PLS).Hasil penelitian menunjukkan nilai koefisien R Square sebesar 0,685 memiliki arti bahwa 68,5 persen variasi dari kualitas Community Based Tourism mampu dijelaskan oleh variasi dari kualitas modal sosial, potensi pariwisata, dan pemberdayaan masyarakat, sedangkan sisanya sebesar 31,5 persen dijelaskan oleh variabel lain yang tidak dimasukkan dalam model. Modal sosial, pemberdayaan dan potensi pariwisata berpengaruh positif dan signifikan terhadap kualitas Community Based Tourism (CBT). Variabel pemberdayaan memoderasi pengaruh modal sosial dan potensi pariwisata terhadap community based tourism (CBT) di Kecamatan Gianyar, Sukawati dan Blahbatuh.

Kata kunci: community based tourism, modal sosial, pemberdayaan, potensi pariwisata.
\end{abstract}

\begin{abstract}
The main goal of development reduces the gap in society, the main challenge of development in our time is the challenge of inclusion. The concept of development for Bali should be adapted to the potential and conditions of Bali itself, always looking closely at the changing gaps that occur all the time. The tourism sector is a potential development to develop. The tourism sector in Bali province is the income-generating sector. The development of tourism sector in Bali spread throughout the district / city, one of which is Gianyar regency. Development of development in tourism sector should be done continuously (sustainable) by utilizing local community as a manager, so as not to shift the tourism paradigm in areas rich in customs, natural potential (rice fields, mountains and sea). Analytical technique used is the analysis of structural equations with alternative Partial Least Square (PLS). The result of research shows that the R Square coefficient value of 0.685 means that 68.5 percent of the variation in the quality of Community Based Tourism can be explained by the variation of the quality of social capital, tourism potential, and community empowerment, while the rest of 31.5 percent is explained by other variables not included in the model. Social capital, empowerment and tourism potential has a positive and significant impact on the quality of Community Based Tourism (CBT). The empowerment variable moderate the influence of social capital and tourism potential to community based tourism (CBT) in Gianyar, Sukawati and Blahbatuh Subdistricts.

Keywords: community based tourism, the social of capital, empowerment, the potential of tourism.
\end{abstract}




\section{PENDAHULUAN}

Tujuan utama pembangunan mengurangi kesenjangan yang terjadi di masyarakat, tantangan utama pembangunan pada jaman kita saat ini adalah tantangan terhadap timbulnya penyatuan (inclusion) (Todaro,2000). Konsep pembangunan untuk Bali seharusnya disesuikan dengan potensi dan kondisi yang dimiliki oleh Bali sendiri, dengan selalu mencermati perubahan kesejagatan yang terjadi setiap saat. Sebelum pembahasan lebih lanjut, untuk lebih mudah memahami ide-ide yang akan dikemukakan, perlu ada satu kesamaan persepsi terkait dengan makna pembangunan.

Hampir semua orang merasa mengerti, tentang kata pembangunan, namun belum tentu memahami secara benar. Berbagai definisi telah digunakan oleh para ahli mengenai pembangunan. Pembangunan harus dipandang sebagai suatu proses yang multidimensional yang mencakup berbagai perubahan mendasar atas struktur sosial, sikap-sikap masyarakat, dan institusi-institusi nasional, di samping tetap mengejar pertumbuhan ekonomi, penanganan ketimpangan pendapatan, serta pengentasan kemiskinan. Lembaga - lembaga yang dibangun untuk mengupayakan terjadinya pembangunan di semua sendi kehidupan. Salah satu syarat untuk mencapai kesejahtraan masyarakat yang seutuhnya adalah harus adanya pembangunan yang berkelanjutan. Bali terlanjur sangat tergantung Sektor Pariwisata, harus lebih serius membuat sebuah strategi pembanguan pariwisata yang lebih menjamin terwujudnya pembangunan berkelanjutan.

Sektor Pariwisata merupakan modal atau potensi yang dimiliki oleh masing-masing daerah, modal berupa sumber daya alam yang dimiliki, kebudayaan, adat-istiadat dan kemampuan pemerintah dan masyarakat mengemas segala keunikan yang dimiliki menjadi sebuah identitas dari daerah tersebut. Provinsi Bali merupakan salah satu daerah dengan potensi pariwisata yang beraneka ragam sehingga mampu dikenal sampai ke mancanegara.Bali dengan julukannya sebagai "Pulau Dewata" tentunya memiliki daya pikat tersendiri untuk menarik wisatawan ingin berkunjung.

Sektor pariwisata di provinsi Bali merupakan sektor penompang pendapatan, hal ini dapat dilihat dari sumbangan sektor pariwisata pada 
Produk Domestik Regional Bruto (PDRB)..Kalau kita amati, Persentase Produk Domestik Regional Bruto (PDRB) Provinsi Bali Tahun 2014-2015, yang terbagi atas lapangan usaha. Lapangan usaha yang paling menompang perekonomian Bali adalah penyediaan akomodasi dan makan minum dan selanjutnya diikuti oleh lapangan usaha Pertanian, Kehutanan, dan Perikanan.

Seperti yang diketahui bersama bahwa perekonomian Bali sangat ditopang oleh industri pariwisata dalam arti luas. Perkembangan pariwisata di Bali pada dasarnya memberikan dampak pengaruh secara langsung terhadap kinerja perekonomian bali, serta memberikan pengaruh langsung dan tidak langsung terhadap perubahan struktur ekonomi masyarakat, akan tetapi terhadap kesejahteraan masyarakat, perkembangan pariwisata di Bali tidak berpengaruh secara signifikan. Perekembangan pariwisata berpengaruh secara tidak langsung terhadap kesejahteraan masyarakat melalui kinerja perekonomian dan perubahan struktur ekonomi, Suyana (2006).

Untuk Daerah Bali, mengingat potensi pariwisata yang sangat besar dimiliki yaitu dari laut, gunung serta sawah serta kondisi wilayah yang sangat kental dengan sosial budayanya (sistem banjar), keyakinan dan kepercayaannya (Tri Kayangan), pola pengeloaan pertaniannya (sistem subak) dan lainnya atau sering disebut modal sosial. Modal sosial (social capital) ini cukup unik, karena sangat jarang dimiliki daerah lain, dengan ini maka model yang relative paling tepat adalah diupayakan secara sungguhsungguh terbentuknya Model Pembangunan Pariwisata Berbasiskan Masyarakat, Community Based Tourism (CBT). Modal sosial menawarkan betapa pentingnya suatu hubungan. Dengan membagun suatu hubungan satu sama lain, dan memeliharanya agar terjalin terus, setiap individu dapat bekerjasama untuk memperoleh hal-hal yang tercapai sebelumnya serta meminimalisasikan kesulitan yang besar.

Model Pembangunan Pariwisata Berbasiskan Masyarakat yang baik dapat tercipta tentunya diperlukan pemberdayaan masyarakat akan potensi pariwisata yang dimiliki baik itu dari sumber daya alam maupun sumber 
daya manusia. Pemberdayaan merupakan proses mendorong individu dalam organisasi untuk menggunakan inisiatif, kewenangan dan tanggung jawab dalam menyelesaikan pekerjaan. Pemberdayaan yang terpenting dilakukan adalah pemberdayaan terhadap sumber daya manusia yang ada, dengan terciptanya SDA yang terdidik, kreatif dan inovatif maka pemanfaatan potensi pariwisata yang dimiliki menjadi lebih efektif.

\section{Gambar 1.1 Distribusi PDRB Atas Dasar Harga Berlaku Tahun 2011-2015} Pada Sektor Pertanian, Industri dan Pariwisata (dalam Persen)

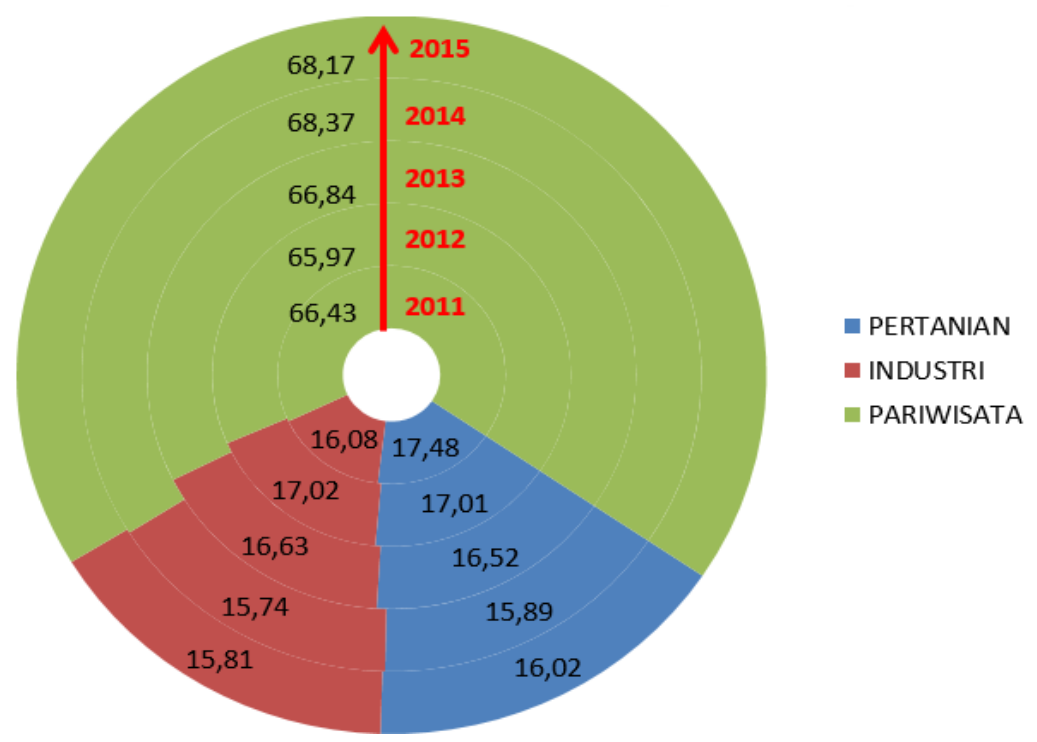

Sumber: Badan Pusat Statistik (2016)

Dari Gambar 1.1 dapat dilihat bahwa sektor pariwisata yang merupakan sektor unggulan di Bali memang menyumbang PDRB paling banyak jika dibandingkan dengan sektor industri dan pertanian.Persentase yang meningkat dari tahun ke tahun merupakan cerminan bahwa pentingnya pembangunan sektor pariwisata sebagai penopang perekonomian Bali. Kontribusi sektor pariwisata terhadap PDRB merupakan salah satu fakta bahwa pariwisata merupakan penyumbang terbanyak terhadap perekonomian.

Perkembangan sektor pariwisata di Bali tersebar di seluruh kabupaten/kota, salah satunya adalah Kabupaten Gianyar. Kabupaten Gianyar merupakan salah satu Kabupaten yang ada di Provinsi Bali, yang 
memiliki keanekaragaman seni, adat dan budaya yang mana masih tetap berkembang dan lestari hingga sekarang, dan juga dikenal sebagai Kabupaten seni. Sebagai daerah tujuan wisata berbagai macam obyek wisata dapat kita temukan di kabupaten Gianyar, seperti objek wisata budaya, objek wisata purbakala, objek wisata remaja, objek wisata bahari, dan objek wisata wana. Dari setiap obyek wisata memiliki suguhan atraksi wisata yang berbeda-beda, sehingga memiliki pesona budaya dan seni tersendiri. Banyak wisatawan yang berkunjung ke daerah ini, baik wisatawan domestik maupun wisatawan mancanegara. Selain itu, banyanknya berbagai macam produk cenderamata yang dihasilkan juga merupakan atraksi yang mengagumkan dan merupakan daya tari wisata.

Sebagai kawasan yang relative baru, pola pengembangan dan tata ruang yang cocok dan pantas untuk kawasan tersebut, sebaiknya sedini mungkin dipersiapkan dengan sungguh-sungguh, diusakan keterlibatan dari semua pihak, agar efek eksternalitas pengembangan dan pembangunan sebuah kawasan bisa diminimalisir, sehingga budaya, lingkungan bisa terjaga dengan baik. Untuk itulah kawasan tersebut sangat strategis untuk segera dilakukan berbagai penelitian-penelitian yang sejalan dengan yang dibutuhan dalam rangka proses pengembangan serta pelestariannya. Maka penelitian ini dilakukan di wilayah Gianyar Selatan yaitu, Kawasan Strategis Pariwisata Lebih, yang mencakup Wilayah Kecamatan Gianyar, Sukawati dan Blahbatuh.

Berdasarkan Monografi Kabupaten Gianyar memiliki beberapa faktor yang dapat menunjang pembangunan kepariwisataan. Faktor-faktor tersebut antara lain: (1) kebudayaan dan kehidupan bermasyarakat bersumber pada kebudayaan dan dijiwai oleh agama Hindu; (2) keindahan alam, peninggalan sejarah dan purbakala sebagai objek wisata yang unik dan mempesona dan tidak ada di daerah lain; (3) fasilitas transportasi dan telekomunikasi yang memadai; (4) fasilitas penunjang lain seperti hotel, home stay, dan restoran yang banyak bertebaran dan mudah didapatkan.

\section{Grafik 1.1 Perbandingan Jumlah Usaha Sebagai Penunjang Pariwisata}


di Gianyar Selatan dan Gianyar Utara Tahun 2016

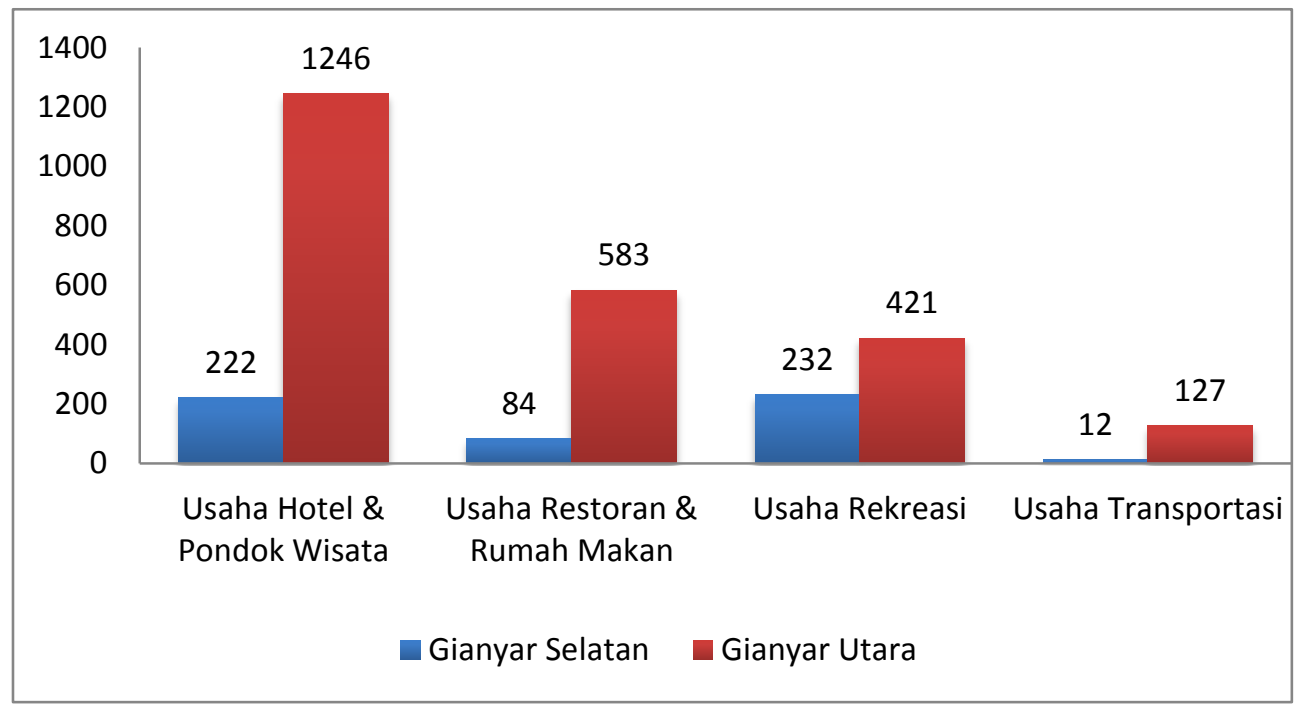

Sumber: Direktori Potensi Pariwisata Kabupaten Gianyar Tahun 2016 (diolah)

Pesatnya perkembangan pariwisata di Kabupaten Gianyar, akan sangat berpengaruh terhadap perkembangan ekonomi masyarakat serta adanya peningkatan pembangunan daerah Gianyar. Akan tetapi terjadinya peningkatan pembangunan di sektor pariwisata tidak diimbangan dengan usaha pemerataan pembangunan. Maka saat ini terlihat telah terjadi disparitas antara Gianyar bagian utara dengan Gianyar bagian selatan, hal ini tampak sangat jelas tergambarkan dalam Grafik 1.1 di atas. Ketimpangan ini untuk jangka panjang sangat tidak baik, dalam rangka mengejar tujuan pembangunan yang seutuhnya, karena akan dapat memicu rasa ketidakadilan dalam masyarakat, yang bisa menimbulkan komplik antar wilayah, hal ini juga sangat mengganggu dalam usaha mewujudkan visi pembangunan pariwisata daerah kabupaten Gianyar yakni, "Terwujudnya pariwisata budaya yang berkualitas, berdaya saing, berkelanjutan dan sejahtra"

Sesuai dengan uraian yang terdapat pada latar belakang, maka dapat dirumuskan pokok permasalahan sebagai berikut:

1) Bagaimanakah pengaruh modal sosial, potensi pariwisata, dan pemberdayaan terhadap Community Based Tourism (CBT) di Kecamatan Gianyar, Sukawati dan Blahbatuh? 
2) Apakah variabel pemberdayaan memoderasi pengaruh modal sosial dan potensi pariwisata terhadap community based tourism(CBT) di Kecamatan Gianyar, Sukawati dan Blahbatuh?

\section{METODELOGI PENELITIAN}

\subsection{Rancangan Penelitian}

Penelitian ini dirancang menggunakan penggabungan pendekatan penelitian yang bersifat kuantitatif dengan tetap mempertimbangkan aspek kualitatif, sebagai pendukung informasi yang relevan dengan kebutuhan penelitian ini. Pendekatan dengan mempertimbangkan aspek kualitatif, karena sangat sering terjadi adanya kesalahan dalam perekaman data, responden yang salah dalam menafsirkan pertanyaan serta kendala lain dalam penelitian seperti salah satu dalam menentukan responden, serta kualitas tenaga lapangan yang kurang memadai.

\subsection{Populasi, Sampel dan Metode Penentuan Sampel}

Populasi adalah seluruh data yang menjadi perhatian kita dalam suatu ruang lingkup dan waktu yang kita tentukan (Margono, 2004). Menurut Sugiyono (2003) populasi adalah wilayah generalisasi yang terdiri atas obyek atau subyek yang mempunyai kuantitas dan karakteristik tertentu yang ditetapkan oleh peneliti untuk dipelajari dan kemudian ditarik kesimpulannya dan dapat diartikan keseluruhan objek atau subjek yang akan diteliti. Populasi penelitian ini adalah seluruh Usaha Pendukung Pariwisata di daerah tujuan wisata yang tercakup dalam Kawasasan Strategis Pariwisata Lebih, yang terletak pada tiga kecamatan di Kabupaten Gianyar Bagian Selatan, terdiri dari Kecamatan Gianyar, Sukawati, dan Blahatuh.

Berdasarkan sebaran data di atas, maka penelitian ini mempergunakan metode penarikan sampel proporsional random sampling (Khotari, 2004; Bein and McKarthy, 2012; Gillham, 2000). Jumlah populasi dalam penelitian ini adalah jumlah usaha pendukung pariwisata yang ada ditiga kecamatan yaitu sebanyak 550 pemilik usaha (Direktori, 2016). Sampel adalah sebagian atau wakil populasi yang diteliti (Furchan, 2004). Sugiyono (2003) 
mengemukakan bahwa sampel adalah sebagian dari jumlah dan karakteristik yang dimiliki oleh populasi.Sampel dalam penelitian ini adalah sebagai berikut: di Kecamatan Gianyar sebanyak 34 responden dan di kecamatan Blahbatuh sebanyak 41 responden dan di Kecamatan Sukawati sebesar 60 responden jadi total sampel sebanyak 135 responden. Metode yang digunakan dalam pengumpulan data adalah menggunakan Teknik Sampel Aksidental (Accidental Sampling) (Margono, 2004)

\section{METODE PENELITIAN}

\subsection{Teknik Analisis Data}

Tujuan PLS adalah membantu untuk tujuan prediksi. Penelitian ini memnggunakan teknik analisis PLS untuk mengukur seberapa keberhasilan community based tourism (CBT) dan untuk mengetahui apakah program community based tourism (CBT) sesuai dengan tujuan dan harapan. Dalam penelitian analisis, PLS digunakan untuk menganalisis pengaruh variabel modal sosial terhadap community based tourism (CBT). Begitupun halnya untuk menganalisis pengaruh modal sosial dengan adanya variable moderasi pemberdayaan terhadap community based tourism (CBT). Selain itu analisis PLS juga digunakan untuk mengetahui variabel modal social berpengaruh terhadap community based taourism (CBT) dengan variable moderasi yaitu pemberdayaan.

\subsection{Model Persamaan Struktural}

Secara keseluruhan full model mengenaipengaruh modal sosial dan potensi pariwisata terhadap Community Based Tourism (CBT) dengan variabel moderasi pemberdayaan di Kecamatan Gianyar, Sukawati dan Blahbatuh ditampilkan pada Gambar 3.1. Berdasarkan full model tersebut selanjutnya dianalisis mengenai validitas konstruk melalui uji outer model dan juga inner model. 


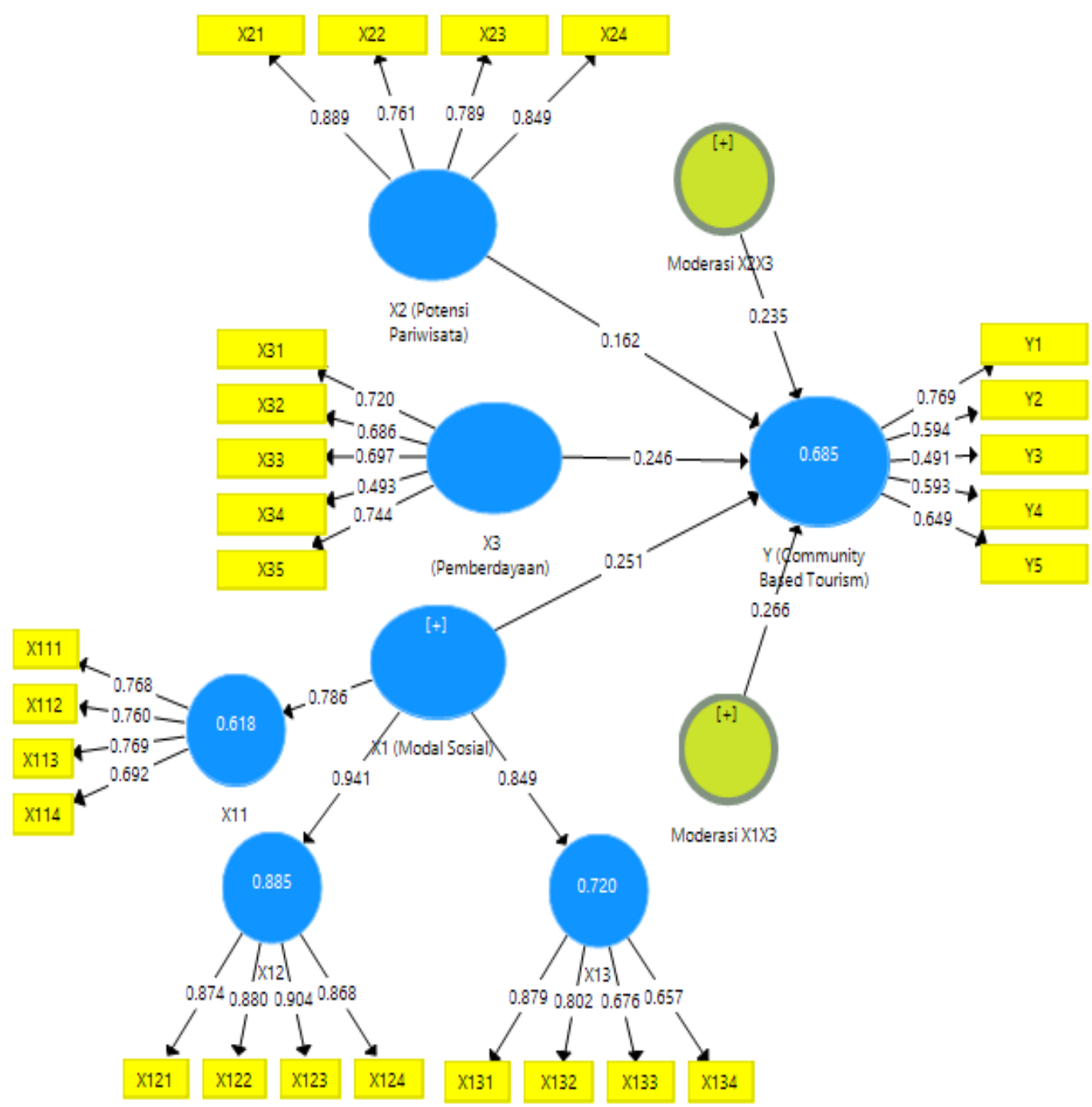

Gambar 3.1.

Full Model Pengaruh Modal Sosial Dan Potensi Pariwisata Terhadap Community Based Tourism (CBT)Dengan Variabel Moderasi Pemberdayaan di Kecamatan Gianyar, Sukawati dan Blahbatuh

\subsection{Uji Validitas Outer Model}

Untuk mengetahui apakah indikator yang digunakan untuk membentuk konstruk atau variabel latent adalah valid, maka berdasarkan Tabel 3.1 dapat diketahui bahwa semua indikator yang membentuk konstruk secara statistik adalah signifikan dengan nilai t hitung lebih besar dari 1,96 dengan $\mathrm{p}$ value sebesar 0,000. Demikian berarti bahwa konstruk yang dibuat telah memenuhi syarat convergent validity.

Tabel 3.1 
Outer Loading Variabel Penelitian

\begin{tabular}{|c|c|c|c|c|c|c|}
\hline \multicolumn{3}{|c|}{ Hubungan Variabel } & \multirow{2}{*}{$\begin{array}{r}\text { Original Sample } \\
0.768\end{array}$} & \multirow{2}{*}{$\begin{array}{r}\text { Std.Deviation } \\
0.043\end{array}$} & \multirow{2}{*}{$\begin{array}{r}\text { T.Statistics } \\
18.056\end{array}$} & \multirow{2}{*}{$\frac{\text { P.Values }}{0.000}$} \\
\hline $\mathrm{X} 111$ & $<-$ & $\mathrm{X} 11$ & & & & \\
\hline $\mathrm{X} 112$ & $<-$ & $\mathrm{X} 11$ & 0.760 & 0.061 & 12.479 & 0.000 \\
\hline X113 & $<-$ & $\mathrm{X} 11$ & 0.769 & 0.071 & 10.767 & 0.000 \\
\hline X114 & $<-$ & $\mathrm{X} 11$ & 0.692 & 0.068 & 10.129 & 0.000 \\
\hline $\mathrm{X} 121$ & $<-$ & $\mathrm{X} 12$ & 0.874 & 0.026 & 33.242 & 0.000 \\
\hline $\mathrm{X} 122$ & $<-$ & $\mathrm{X} 12$ & 0.880 & 0.020 & 44.977 & 0.000 \\
\hline $\mathrm{X} 123$ & $<-$ & $\mathrm{X} 12$ & 0.845 & 0.030 & 28.136 & 0.000 \\
\hline $\mathrm{X} 124$ & $<-$ & $\mathrm{X} 12$ & 0.868 & 0.025 & 34.800 & 0.000 \\
\hline $\mathrm{X} 131$ & $<-$ & $\mathrm{X} 13$ & 0.879 & 0.021 & 41.987 & 0.000 \\
\hline $\mathrm{X} 132$ & $<-$ & $\mathrm{X} 13$ & 0.802 & 0.059 & 13.592 & 0.000 \\
\hline $\mathrm{X} 133$ & $<-$ & $\mathrm{X} 13$ & 0.676 & 0.107 & 6.302 & 0.000 \\
\hline X134 & $<-$ & $\mathrm{X} 13$ & 0.657 & 0.106 & 6.219 & 0.000 \\
\hline $\mathrm{X} 21$ & $<-$ & $\mathrm{X} 2$ & 0.889 & 0.025 & 36.139 & 0.000 \\
\hline $\mathrm{X} 22$ & $<-$ & $\mathrm{X} 2$ & 0.761 & 0.060 & 12.762 & 0.000 \\
\hline $\mathrm{X} 23$ & $<-$ & $\mathrm{X} 2$ & 0.789 & 0.064 & 12.326 & 0.000 \\
\hline X24 & $<-$ & $\mathrm{X} 2$ & 0.849 & 0.048 & 17.764 & 0.000 \\
\hline X31 & $<-$ & $\mathrm{X} 3$ & 0.720 & 0.088 & 8.174 & 0.000 \\
\hline X32 & $<-$ & $\mathrm{X} 3$ & 0.686 & 0.081 & 8.517 & 0.000 \\
\hline X33 & $<-$ & $\mathrm{X} 3$ & 0.697 & 0.089 & 7.807 & 0.000 \\
\hline X34 & $<-$ & X3 & 0.493 & 0.117 & 4.224 & 0.000 \\
\hline X35 & $<-$ & $\mathrm{X} 3$ & 0.744 & 0.072 & 10.289 & 0.000 \\
\hline Y1 & $<-$ & $\mathrm{Y}$ & 0.769 & 0.040 & 19.241 & 0.000 \\
\hline Y2 & $<-$ & $\mathrm{Y}$ & 0.594 & 0.086 & 6.881 & 0.000 \\
\hline Y3 & $<-$ & $\mathrm{Y}$ & 0.491 & 0.125 & 3.919 & 0.000 \\
\hline Y4 & $<-$ & Y & 0.591 & 0.860 & 6.898 & 0.000 \\
\hline Y5 & $<-$ & $\mathrm{Y}$ & 0.649 & 0.088 & 7.417 & 0.000 \\
\hline
\end{tabular}

Sumber: Data Diolah, 2017.

\subsection{Discriminan Validity}

Untuk mengetahui validitas suatu konstruk juga dapat dilihat dari discriminan validity. Discriminan validity pada indikator reflektif adalah dengan melihat crossloading indikator terhadap konstruk atau latennya. DV yang bagus yang mana indikatornya memiliki crossloading pada konstruknya lebih besar dibandingkan dengan konstruk lainnya.

Tabel 3.2

Cross Loading Variabel Penelitian

\begin{tabular}{lllllll}
\hline Variabel & X11 & X12 & X13 & X2 & X3 & Y \\
\hline X111 & $\mathbf{0 . 7 6 8}$ & 0.477 & 0.410 & 0.159 & 0.156 & 0.324 \\
X112 & $\mathbf{0 . 7 6 0}$ & 0.418 & 0.379 & 0.171 & 0.081 & 0.290
\end{tabular}




\begin{tabular}{lrrrrrr} 
X113 & $\mathbf{0 . 7 6 9}$ & 0.517 & 0.273 & 0.314 & 0.238 & 0.424 \\
X114 & $\mathbf{0 . 6 9 2}$ & 0.470 & 0.359 & 0.192 & 0.214 & 0.350 \\
X121 & 0.562 & $\mathbf{0 . 8 7 1}$ & 0.599 & 0.619 & 0.380 & 0.501 \\
X122 & 0.516 & $\mathbf{0 . 8 8 0}$ & 0.733 & 0.455 & 0.333 & 0.358 \\
X123 & 0.585 & $\mathbf{0 . 9 0 1}$ & 0.744 & 0.588 & 0.349 & 0.514 \\
X124 & 0.558 & $\mathbf{0 . 8 6 8}$ & 0.473 & 0.575 & 0.312 & 0.466 \\
X131 & 0.759 & 0.692 & $\mathbf{0 . 8 7 9}$ & 0.277 & 0.288 & 0.483 \\
X132 & 0.704 & 0.594 & $\mathbf{0 . 8 0 2}$ & 0.255 & 0.320 & 0.430 \\
X133 & 0.443 & 0.328 & $\mathbf{0 . 6 7 6}$ & -0.168 & -.181 & 0.149 \\
X134 & 0.608 & 0.522 & $\mathbf{0 . 6 5 7}$ & 0.255 & 0.148 & 0.375 \\
X21 & 0.531 & 0.610 & 0.455 & $\mathbf{0 . 8 8 9}$ & 0.063 & 0.484 \\
X22 & 0.418 & 0.460 & 0.306 & $\mathbf{0 . 7 6 1}$ & 0.000 & 0.357 \\
X23 & 0.213 & 0.341 & 0.040 & $\mathbf{0 . 7 8 9}$ & 0.092 & 0.235 \\
X24 & 0.512 & 0.600 & 0.375 & $\mathbf{0 . 8 4 9}$ & 0.167 & 0.372 \\
X31 & 0.148 & 0.164 & 0.112 & 0.163 & $\mathbf{0 . 7 2 0}$ & 0.454 \\
X32 & 0.146 & 0.177 & 0.041 & 0.239 & $\mathbf{0 . 6 8 6}$ & 0.436 \\
X33 & 0.163 & 0.372 & 0.533 & 0.300 & $\mathbf{0 . 6 9 7}$ & 0.342 \\
X34 & -0.062 & -0.056 & -0.008 & -0.095 & $\mathbf{0 . 4 9 3}$ & 0.153 \\
X35 & 0.317 & 0.498 & 0.568 & 0.135 & $\mathbf{0 . 7 4 4}$ & 0.462 \\
Y1 & 0.470 & 0.433 & 0.513 & 0.422 & 0.447 & $\mathbf{0 . 7 6 9}$ \\
Y2 & 0.241 & 0.318 & 0.181 & 0.376 & 0.419 & $\mathbf{0 . 4 9 4}$ \\
Y3 & 0.120 & 0.006 & 0.134 & 0.006 & 0.301 & $\mathbf{0 . 4 9 1}$ \\
Y4 & 0.355 & 0.288 & 0.364 & 0.172 & 0.345 & $\mathbf{0 . 5 9 1}$ \\
Y5 & 0.236 & 0.438 & 0.322 & 0.322 & 0.309 & $\mathbf{0 . 6 4 9}$ \\
\hline S4
\end{tabular}

Sumber :Data Diolah, 2017.

Berdasarkan Tabel 3.2 dapat diketahui bahwa discrimanant validity sudah terpenuhi dengan melihat crossloading sudah terpenuhi dengan bagus karena indikatornya memiliki crossloading lebih pada konstruknya dibandingkan terhadap konstruk lainnya. Sebagai contoh konstruk X111 memiliki crossloading minimal 0,678, sedangkan pada konstruk lainnya indikatornya memiliki crossloading lebih kecil dari nilai itu, yaitu paling besar sebesar 0,477.Kelayakan konstruk yang dibuat juga dapat dilihat dari discrimanant validity (DV) melalui Average Variance Extracted (AVE). Hasil olahan datanya disajikan pada Tabel 3.3

Tabel 3.3

Average Variance Extracted (AVE) Variabel Penelitian

\begin{tabular}{lllcc}
\hline & Original & Std & & \\
Variabel & Sample & Deviation & T.Statistics & P.Values \\
\hline X11 & 0.480 & 0.046 & 12.175 & 0.000 \\
X12 & 0.559 & 0.026 & 29.441 & 0.000 \\
X13 & 0.777 & 0.050 & 11.464 & 0.000 \\
X1 & 0.576 & 0.032 & 15.042 & 0.000
\end{tabular}




\begin{tabular}{lllll} 
X2 & 0.678 & 0.039 & 17.542 & 0.000 \\
X3 & 0.454 & 0.044 & 10.293 & 0.000 \\
Y & 0.392 & 0.034 & 11.490 & 0.000 \\
\hline
\end{tabular}

Sumber: Data Diolah, 2017.

Berdasarkan tabel 3.3 dapat diketahui bahwa konstruk sangat bagus, karena mimiliki discrimanant validity yaitu Average Variance Extracted (AVE) semuanya signifikan, atau dengan P.Value yang lebih kecil dari 0,05. Nilai AVE minimal 0.392, dan maksimal sebesar 0,777.

Selanjutnya diperhatikan juga Composite reliability ( $\rho$ ) yang umumnya digunakan untuk indikator reflektif yang bertujuan untuk mengukur konsistensi internal suatu konstruk. Hasil olahan datanya disajikan pada Tabel 3.4. Berdasarkan Tabel 3.4 dapat diketahui bahwa semua konstruk mimiliki tingkat signifikansi lebih kecil dari 0,05 dan koefisien Composite Reliability lebih besar dari 0,70. Hal ini berarti semua konstruk memiliki konsistensi internal yang tinggi.

Tabel 3.4

Composite Reliability Variabel Penelitian

\begin{tabular}{lcccc}
\hline Variabel & $\begin{array}{l}\text { Original } \\
\text { Sample }\end{array}$ & $\begin{array}{l}\text { Std } \\
\text { Deviation }\end{array}$ & T.Statistics & P.Values \\
\hline X11 & 0.885 & 0.026 & 31.527 & 0.000 \\
X12 & 0.933 & 0.010 & 97.158 & 0.000 \\
X13 & 0.842 & 0.031 & 27.310 & 0.000 \\
X1 & 0.915 & 0.011 & 81.928 & 0.000 \\
X2 & 0.894 & 0.018 & 49.902 & 0.000 \\
X3 & 0.803 & 0.035 & 23.055 & 0.000 \\
Y & 0.759 & 0.030 & 25.534 & 0.000 \\
\hline
\end{tabular}

Sumber: Data Diolah, 2017.

Disamping itu, suatu konstruk juga dilihat reliabilitasnya melalui Cronbach Alpha. Nilai Cronbach Alpha diharapkan lebih besar dari 0.60. Namun menurut Chin (dalam Gozali, 2011) angka itu bukan harga mati, asalkan konstruk tersebut signifikan. Hasil olahan data dapat dilihat pada Tabel 3.5 
Cronbach AlphaVariabel Penelitian

\begin{tabular}{ccccc}
\hline Variabel & $\begin{array}{c}\text { Original } \\
\text { Sample }\end{array}$ & $\begin{array}{l}\text { Std } \\
\text { Deviation }\end{array}$ & T.Statistics & P.Values \\
\hline X11 & 0.736 & 0.051 & 14.310 & 0.000 \\
X12 & 0.904 & 0.015 & 61.171 & 0.000 \\
X13 & 0.750 & 0.059 & 12.677 & 0.000 \\
X1 & 0.896 & 0.015 & 59.309 & 0.000 \\
X2 & 0.844 & 0.024 & 34.652 & 0.000 \\
X3 & 0.706 & 0.051 & 13.963 & 0.000 \\
Y & 0.603 & 0.063 & 9.559 & 0.000 \\
\hline
\end{tabular}

Sumber: Data Diolah, 2017.

Dari Tabel 3.5 dapat dilihat bahwa semua konstruk memiliki signifikansi kurang dari 0,000 dan memiliki nilaiCronbach Alphalebih dari 0,60. Hal ini dapatdisimpulkan bahwa semua konstruk adalah reliabel. Dengan nilai koefisien R Square sebesar 0,685 memiliki arti bahwa 68,5 persen variasi dari kualitas Community Based Tourism di Kecamatan Gianyar, Sukawati dan Blahbatuh, mampu dijelaskan oleh variasi dari kualitas modal sosial, potensi pariwisata, dan pemberdayaan masyarakat, serta Interaksi antara modal sosial dengan pemberdayaan, dan interaksi antara potensi pariwisata dengan pemberdayaan, sedangkan sisanya sebesar 31,5 persen dijelaskan oleh variabel lain yang tidak dimasukkan dalam model.

\subsection{Uji Inner Model}

Uji inner model yang disebut juga pengujian antar konstruk pertama-tama dilakukan dengan melihat pengaruh langsung suatu variabel independen terhadap variabel dependen yang diuji melalui path coefficient, seperti yang disajikan pada Tabel 3.6

Tabel 3.6

Path Coefficient Hubungan Antar Konstruk Penelitian

\begin{tabular}{|c|c|c|c|c|c|c|}
\hline \multicolumn{3}{|c|}{ Hubungan Variabel } & \multirow{2}{*}{$\begin{array}{l}\begin{array}{l}\text { Original } \\
\text { Sample }\end{array} \\
0.251\end{array}$} & \multirow{2}{*}{$\begin{array}{l}\text { Std } \\
\text { Deviation } \\
0.079\end{array}$} & \multirow{2}{*}{$\frac{\text { T.Statistics }}{3.170}$} & \multirow{2}{*}{$\frac{\text { P.Values }}{0.002}$} \\
\hline $\mathrm{X} 1$ & $\rightarrow$ & $\mathrm{Y}$ & & & & \\
\hline $\mathrm{X} 2$ & $\rightarrow$ & $\mathrm{Y}$ & 0.162 & 0.074 & 2.185 & 0.029 \\
\hline X3 & $\rightarrow$ & $\mathrm{Y}$ & 0.246 & 0.089 & 2.756 & 0.006 \\
\hline X1X3 & $\rightarrow$ & $\mathrm{Y}$ & 0.266 & 0.105 & 2.545 & 0.011 \\
\hline
\end{tabular}


$\mathrm{X} 2 \mathrm{X} 3$

Sumber: Data diolah, 2017

Keterangan:

$\mathrm{X} 1=$ modal sosial

$\mathrm{X} 2=$ potensi pariwisata

$\mathrm{X} 3$ = pemberdayaan

$\mathrm{Y}=$ Community Based Tourism (CBT)

Berdasarkan Tabel 3.6 diketahui bahwa modal sosial (X1), potensi pariwisata (X2), dan pemberdayaan (X3) berpengaruh positif dan signifikan terhadap Community Based Tourism (Y), dengan P. Value atau tingkat signifikansi masing-masing sebesar 0,002; 0,029, dan 0,006. Hal ini berarti bahwa semakin baik kualitas modal sosial, potensi pariwisata, dan pemberdayaan masyarakat, maka semakin baik juga kualitas Community Based Tourismdi Kecamatan Gianyar, Sukawati dan Blahbatuh.

Interaksi antara modal sosial dengan pemberdayaan, dan interaksi antara potensi pariwisata dengan pemberdayaan berpengaruh signifikan terhadap Community Based Tourism, dengan P. Values masing-masing sebesar 0,011 dan 0,017 atau kurang dari 0,05. Hal ini dapat disimpulkan bahwa variabel pemberdayaan memoderasi pengaruh modal sosial dan potensi pariwisata terhadap Community Based Tourism. Kondisi ini dapat diartikan bahwa dengan kualitas modal sosial dan potensi pariwisata yang konstan, namun dengan meningkatnya kualitas pemberdayaan masyarakat maka pengaruh modal sosial dan potensi pariwisata terhadap kualitas Community Based Tourism (CBT) menjadi meningkat di Kecamatan Gianyar, Sukawati dan Blahbatuh. 


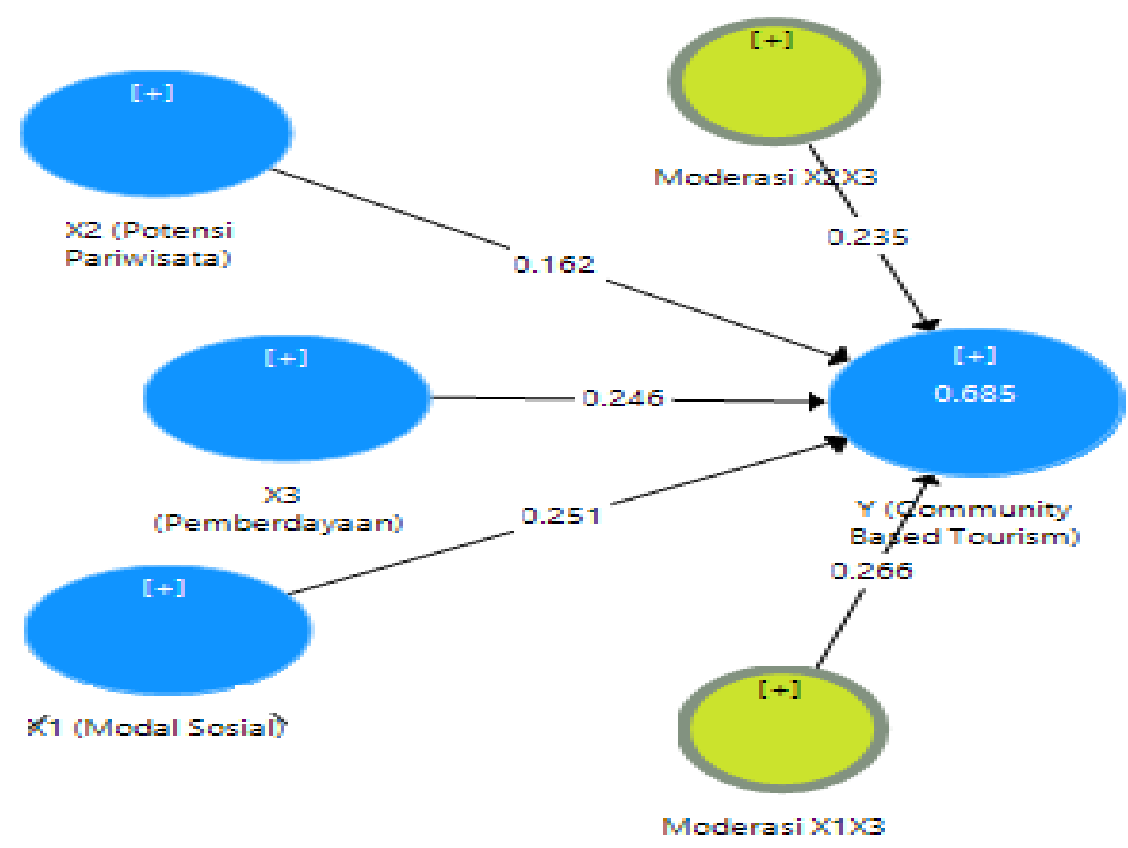

Gambar 3.2

Diagram Hubungan Variabel Penelitian

Berdasarkan Gambar 3.2 dapat dijelaskan bahwa variabel yang lebih berpengaruh terhadap Community Based Tourismdi (CBT) Kecamatan Gianyar, Sukawati dan Blahbatuh berturut-turut: interaksi antara modal sosial dengan pemberdayaan dengan path coefficient sebesar 0,266, kemudian disusul oleh variabel modal sosial sebesar 0,251 , dan yang paling kecil adalah variabel potensi pariwisata sebesar 0,162 .

\section{PEMBAHASAN}

\subsection{Pengaruh modal sosial terhadap Community Based Tourism (CBT) di} Kecamatan Gianyar, Sukawati dan Blahbatuh

Pengaruh modal sosial terhadap Community Based Tourism (CBT) dapat dilihat dari nilai P. Values sebesar 0,002 kurang dari 0,05 dan nilai T.Statistic 3.170. Hal ini dapat disimpulkan bahwa secara statistik modal sosial berpengaruh positif terhadap Community Based Tourism (CBT) di Kecamatan Gianyar, Sukawati dan Blahbatuh. Hal ini berarti bahwa dengan meningkatkan kualitas modal sosial di wilayah penelitian, semakin bagus kualitas Community Based 
Tourism (CBT) di Kecamatan Gianyar, Sukawati dan Blahbatuh. Indikator modal sosial menyebabkan meningkatnya indikator CBT, indikator modal sosial antara lain norma, kepercayaan dan jaringan. Studi yang dilakukan Capaye (2000), dan Kimmo (2010), menyatakan pembentukan social capital tidak berdiri sendiri, melainkan merupakan proses yang berkaitan dengan dukungan tradisi, norma masyarakat serta semangat tradisi kebersamaan yang berjalan searah dengan dinamika komponen pendukung sosial ekonomi lainnya.

Penelitian Lynn (2003) menyebutkan dalam pariwisata berkelanjutan sebelumnya telah menulis tentang promosi berbasis masyarakat-pariwisata sebagai sarana untuk mencapai tujuan pembangunan berkelanjutan. Beberapa peneliti telah menyebutkan bahwa pariwisata berbasis masyarakat, dengan sendirinya, tidak selalu mengarah pada praktek-praktek berkelanjutan. Hal ini sesuai dengan modal sosial dalam bentuk networking mempengaruhi pembangunan berkelanjutan.

\subsection{Pengaruh potensi pariwisata terhadap Community Based Tourism(CBT) di Kecamatan Gianyar, Sukawati dan Blahbatuh}

Pengaruh potensi pariwisata terhadap Community Based Tourism (CBT) dapat dilihat dari nilai P. Values sebesar 0,029 kurang dari 0,05 dan nilai T.Statistic 2.185. Hal ini dapat disimpulkan bahwa secara statistik potensi pariwisata berpengaruh positif terhadap Community Based Tourism (CBT) di Kecamatan Gianyar, Sukawati dan Blahbatuh, Indikator dari Potensi Pariwisata menyebabkan meningkatnya indikator Community Based Tourism (CBT). Hal ini berarti bahwa dengan meningkatkan kualitas potensi pariwisata di wilayah penelitian, semakin bagus kualitas Community Based Tourism (CBT) di Kecamatan Gianyar, Sukawati dan Blahbatuh.

Pembangunan pariwisata harusnya berprinsip pada pariwisata berbasis masyarakat yaitu dari rakyat oleh rakyat dan untuk rakyat. Menurut Yoeti, (1996) terdapat empat aspek yang harus diperhatikan untuk pembangunan pariwisata yang berkelanjutan antara lain :Attraction (daya tarik), Accesibility (aksesibilitas), Amenities (fasilitas) dan Ancilliary (Kelembagaan). Potensi obyek wisata juga terjadi karena suatu proses yang dapat disebabkan budidaya manusia. Sukardi 
(1998), potensi wisata adalah sesuatu yang dapat dikembangkan menjadi daya tarik sebuah obyek wisata. Semakin banyak potensi wisata yang dimiliki maka akan semakin tinggi pula kunjungan wisatawan.

\subsection{Pengaruh pemberdayaan terhadap Community Based Tourism (CBT) di}

\section{Kecamatan Gianyar, Sukawati dan Blahbatuh}

Pengaruh pemberdayaan terhadap Community Based Tourism (CBT) dapat dilihat dari nilai P. Values sebesar 0,006 kurang dari 0,05 dan nilai T.Statistic 2.756. Hal ini dapat disimpulkan bahwa secara statistik, Pemberdayaan berpengaruh positif terhadap Community Based Tourism (CBT) di Kecamatan Gianyar, Sukawati dan Blahbatuh. Hal ini berarti bahwa dengan meningkatkan kualitas pemberdayaan di wilayah penelitian, semakin bagus kualitas Community Based Tourism (CBT) di Kecamatan Gianyar, Sukawati dan Blahbatuh.

Indikator Pemberdayaan menyebabkan meningkatnya indikator CBT, indikator pemberdayaan antara lain penyadaran masyarakat, sosialisasi, pengkapasitasan, pemberian bantuan dan kontinuitas program pemberdayaan. Pemberdayaan merupakan adalah proses mendorong suatu individu yang ada di dalam suatu organisasi untuk menggunakan inisiatif, kewenangan dan tanggung jawab dalam menyelesaikan pekerjaan.

\subsection{Pengaruh peran variabel pemberdayaan memoderasi pengaruh modal} sosial dan potensi pariwisata terhadap community based tourism (CBT) di Kecamatan Gianyar, Sukawati dan Blahbatuh.

Pengaruh variabel pemberdayaan memoderasi pengaruh modal sosial dan potensi pariwisata terhadap Community Based Tourism (CBT) dapat dilihat dari nilaiP. Values masing-masing sebesar 0,011 dan 0,017 atau kurang dari 0,05. Hal ini dapat disimpulkan bahwa variabel pemberdayaan memoderasi pengaruh modal sosial dan potensi pariwisata terhadap Community Based Tourism (CBT). Kondisi ini dapat diartikan bahwa dengan kualitas modal sosial dan potensi pariwisata yang konstan, namun dengan meningkatnya kualitas pemberdayaan masyarakat maka pengaruh modal sosial dan potensi pariwisata terhadap kualitas Community Based Tourism (CBT) menjadi meningkat di Kecamatan Gianyar, Sukawati dan Blahbatuh. 
Meningkatkatnya pengaruh modal sosial dan potensi pariwisata akan berpengaruh terhadap semakin bagusnya kualitas Community Based Tourism (CBT) di Kecamatan Gianyar, Sukawati dan Blahbatuh melalui peningkatan kualitas pemberdayaan di lokasi penelitian. Masing-masing indikator dari modal sosial, potensi parisiwata, Community Based Tourism (CBT) akan semakin baik dengan adanya variabel pemberdayaan berserta indikatornya. Hal ini dapat diartikan bahwa dengan kualitas modal sosial dan potensi pariwisata yang konstan, namun dengan meningkatnya kualitas pemberdayaan masyarakat maka pengaruh modal sosial dan potensi pariwisata terhadap kualitas Community Based Tourism (CBT) di Kecamatan Gianyar, Sukawati dan Blahbatuh menjadi meningkat. Dengan Modal Sosial dan Potensi Pariwisata yang sama, meningkatnya Pemberdayaan, maka Community Based Tourism (CBT) meningkat.

\section{Simpulan}

Berdasarkan pengujian hipotesis dan pembahasan dapat ditarik kesimpulan sebagai berikut.

1) Modal sosial, potensi pariwisata, dan pemberdayaan berpengaruh positif dan signifikan terhadap Community Based Tourism (CBT) di Kecamatan Gianyar, Sukawati dan Blahbatuh. Hal ini berarti bahwa semakin baik kualitas modal sosial, potensi pariwisata, dan pemberdayaan masyarakat, maka kualitas Community Based Tourism (CBT) menjadi semakin baik di Kecamatan Gianyar, Sukawati dan Blahbatuh.

2) Variabel pemberdayaan memoderasi pengaruh modal sosial dan potensi pariwisata terhadap Community Based Tourism (CBT) di Kecamatan Gianyar, Sukawati dan Blahbatuh. Hal ini dapat diartikan bahwa dengan kualitas modal sosial dan potensi pariwisata yang konstan, namun dengan meningkatnya kualitas pemberdayaan masyarakat maka pengaruh modal sosial dan potensi pariwisata terhadap kualitas Community Based Tourism (CBT) di Kecamatan Gianyar, Sukawati dan Blahbatuh menjadi meningkat.

\section{Saran}

Adapun saran dari hasil dan pembahasan penelitian adalah sebagai berikut 
Potensi pariwisata memiliki interaksi yang paling kecil diantara variabel lainnya. Artinya untuk meningkatkan kualitas Community Based Tourism (CBT) menjadi semakin baik potensi pariwisata yang merupakan potensi dari alam, budaya dan manusia tidak menjadi hal yang utama sebaiknya variabel lainnya yang berpengaruh lebih besar untuk ditingkatkan kualitasnya. Pemberdayaan merupakan variabel yang paling besar berpengaruh terhadap peningkatan kualitas Community Based Tourism (CBT). Peningkatan intensitas pemberdayaan pada lokasi pariwisata merupakan hal yang penting untuk pembangunan pariwisata. Pemberdayaan yang dilakukan sebaiknya melibatkan masyarakat lokal, sehingga pembangunan pariwisata tidak hanya dirasakan oleh orang yang memiliki investasi, tetapi juga dirasakan oleh masyarakat yang ada di sekitar lokasi pariwisata. Pemberdayaan terutama harus dilakukan oleh Pemerintah, dalam hal ini Pemerintah Daerah, karena pemerintah memiliki keunggulan fiskal dan program-program pemberdayaan, sebagai stimulus dalam mendorong semangat masyarakat untuk berperan serta dalam memajukan perekonomian daerahnya.

\section{DAFTAR PUSTAKA}

Badan Pusat Statistik Provinsi Bali. 2014. Bali Dalam Angka Data Produk Domestik Regional Bruto Provinsi Bali Atas Dasar Harga Konstan Menurut Lapangan Usaha Tahun 2010-2014 (dalam Persen)

Badan Pusat Statistik Provinsi Bali. 2015. Gianyar Dalam Angka. Letak Geografis, Luas dan Topografi di Kabupaten Gianyar.

Badan Pusat Statistik, 2016. Tinjauan Perekonomian Bali.

Cavaye, J.2011,The Role of Government in Community Capacity Building. Journal of Hospitality \& Tourism, Vol. 5, Issue.

Pemerintah Kabupaten Gianyar, Buku Direktori, 2016.

Furchan, A, 2004.Pengantar Penelitian dalam Pendidikan. Yogyakarta: Pustaka Pelajar.

Gillham Bill, 2000,Case Study Research Methods,Padstow, Cornwall.Wellington House 125 Strand London.

Ghozali, I. 2011. Structural Equation Modeling Metode Alternatif dengan Partial Least Square.Edisi 3.Semarang : Universitas Diponegoro. 
Kothari, C.R, 2004, Research Methodology, Methods and Tech, New Age International (P) Ltd., Publishers

Kimmo, O. 2010.Local Government Association Capacity Building - Rationale, Cooperation Practice, and Strategies for the Future, Local and Regional Gov. Finland

Lynn, H. 2003. Making Community-based Tourism Work : An Assessment of Factors Contributing to Successful Community-owned Tourism Development in Namibia. DRD Papers

Margono, 2004.Metodologi Penelitian Pendidikan. Jakarta: Rineka Cipta.

Suyana Utama. I Made. 2006. Pengaruh Perkembangan Pariwisata Terhadap Kinerja Perekonomian dan Perubahan Struktur Ekonomi serta Kesejahteraan Masyarakat di Provinsi Bali.Program Pascasarjana Universitas Airlangga Surabaya (Disertasi).

Sugiyono. 2003. Metode Penelitian Bisnis. Bandung: Alfabeta.

Sukardi, Nyoman. 1998. Pengantar Pariwisata. Bali: Sekolah Tinggi Pariwisata Nusa Dua.

Todaro, Michael P, 2000. Pembangunan Ekonomi di Dunia Ketiga, Jakarta : Penerbit Erlangga.

Yoeti Oka A.1996. Pengantar Ilmu Pariwisata. Bandung:Penerbit Angkasa 